УДК 821.163.41.09-2 Костић Л. https://doi.org/10.18485/godisnjak.2017.12.14

\author{
Јована Д. Милованчевић* \\ Универзитет у Београду \\ Филолошки факултет, студент
}

Оригинални научни рад

Примљен: 6. 10. 2017.

Прихваћен: 23. 10. 2017.

\title{
ПЛАТОНОВСКИ КОНЦЕПТ ЛЕПОТЕ И ЉУБАВИ У ДРАМИ „МАКСИМ ЦРНОЈЕВИЋ” ЛАЗЕ КОСТИЋ
}

\begin{abstract}
Однос лепоте и љубави сагледан кроз призму Платонових дијалога исписаних у „Гозби”, једна је од упоришних тема за разумевање драме „Максим Црнојевић” Лазе Костића. У њој се испитују границе схватања лепоте као физичког догађаја и тражи се могућност њеног духовног сагледавања. Поставља се питање о томе шта лепота јесте и да ли у њој има нешто од нарцисоидног схватања ње саме. Којим се све средствима дочарава њена посебност и да ли се губљењем лепе појавности губи и суштина бића? Платон је говорио о потреби вољења лепе душе. У том смислу овај рад расправља о томе да ли је Анђелија кадра да воли правом љубављу? Разлике које Платон прави у поимању Ерота, могу да помогну у одговору на питање, које све врсте љубави имамо прилике да уочимо у поменутој драми? Може ли се волети физичка ругоба и зашто она у идеалном поретку осећајности и не постоји?
\end{abstract}

Кључне речи: Платон, Максим Црнојевић, лепота, љубав, Ерот, нарцисоидност, ружноћа, душа, Лаза Костић, српски романтизам.

Љубав се рађа само у савршеној лепоти и за њу је суштински везана, зато што су се Ерот ${ }^{1}$ и Афродита родили истог дана. То порађање љубави

*jmilovancevic@yahoo.com

${ }^{1}$ У даљем тексту појам Ерот користиће се у значењу Бога, на начин на који се о њему говори у Платоновој „Гозби“. 
из лепоте једини је могући пут обожења човека и зато Аница СавићРебац наводи да је само Платонов Ерот кроз векове омогућио „песму о трансцеденцији љубави" (Савић-Ребац 1966: 29). Љубав је за старе Грке била врхунско начело и о њеној природи вековима се расправљало. У Платоновој „Гозби”, Диотима каже да Ерот није ништа друго до „љубав за лепотом”, а лепота мора бити хармонична и представљати „стремљење ка бесмртности”, зато што је „Ерот пратилац Афродитин” (Деретић 2014: 129). У том смислу: „лепота и љубав постоје заједно и садрже се једно у другоме, јер љубави за ругобом нема" (Платон 2008: 69). Њихов однос апсолутно је реципрочан и зависан али поставља се питање о којој врсти љубави и лепоте се мора говорити код Платона. Да ли романтичарски субјект преузима само основно начело античке класичности, а у себи на неки начин преобликује њен смисао? Може ли се волети физичка ругоба и да ли се та појавна дисхармонија лица осликава и на ругобу душе? Диотима каже да је за лепоту везано добро, као врхунско начело квалитета те душе. Може ли добро постати валидно само за себе и који је тај тренутак када почиње расправа о лепоти душе, независно од лепоте појавности? Максим Црнојевић, Лазе Костића, био је лепо биће, слично хеленским боговима, али у једном тренутку та лепота је постала зло и претворила се у ругобу. Тада се мисао окренула љубави. О љубави се почело размишљати на оном месту где је престала лепота. Питање се поставља, да ли је љубав била важна и док је било лепоте и ко је у тој драми르 кога волео? У Платоновој „Гозби”, Федар каже да љубав мора бити посвећена племенитом бићу и да само на тај начин постаје и сама племенита (Платон 2008:21). Да ли је Максим Црнојевић своју љубав везао за биће недостојно такве љубави? У потрагу за сопственим ликом кренуо је у тренутку када је његово право лице постало маска или онда када је он сам постао маска самога себе.

Расправа о односу лепоте и љубави у драми „Максим Црнојевић”, поставља и питање о схватању једног од та два различита појма. Лепота је за Лазу Костића била врхунско начело, али у тој лепоти било је и нечег необичног. Он је њу везао за класични грчки моменат хармоније и симетрије, али у њу је унео и нешто друго: „народна поезија блиска грчкој по осећању важности лепоте али је у нечему чак и надмаша - по томе што је лепота код нас и коб" (Несторовић 2007: 178). Коб Максима Црнојевића била је последица велике лепоте, оне која је постојала и оне о којој се причало. О природи те велике лепоте ваља причати на начин класични и схватити зашто велика лепота смртног бића није дозвољена. Овде она сама по себи није пресудна и утемељујућа чињеница драме,

${ }^{2}$ Мисли се на драму Максим Црнојевић, која је предмет овог рада. 
она је само повод за размишљање о дубљој суштини бића. Ерос, према Аници Савић-Ребац, мора бити „уздизање” и „обожење”, а ерос у себи садржи лепоту. Остаје питање, може ли се уздизати до изједначавања са божанским и шта је цена таквог подухвата. Може ли се волети Максим и зашто он, према оној концепцији коју нуди платоновска парадигма љубави и лепоте, није ружан?

\section{„Максим није Нарцис. Нарцис су други.” ${ }^{3}$}

„Шаровите птице немају намере да се надмећу, зато што им је перната лепота довољна”, пише Лаза Костићу у тексту „Основи лепоте у свету” (Костић 1965: 94). Лепота за њих је утемељујућа ознака бића и трагање за другојачијом суштином постаје излишно. Живи се за лепоту и она постаје исходиште и упориште постојања. Све је доведено до краја. Где се налази тај крај у сагледавању људског бића и зашто лепота не може бити, као и код птица, основно одређење човека? То врло лепо можемо видети на примеру лика Максима Црнојевића. Он постоји у свести других као савршено лепо биће и на том миту о његовој појавности развија се мит о вредности читавог његовог окружења (в, Несторовић 2007: 199). У дубљем промишљању ове теме, закључујемо да Максим није могао да поднесе пасивну позицију лепоте са којом је рођен и решио је да се надмеће и одређује у љубави.

Пре свега треба схватити суштинску карактеристику његове лепоте. То је за друге физичка лепота. На самом почетку призива се антички мит о Нарцису. Нарцис је нагнут над својом сенком у води, оној мирној која преображава могуће недостатке и нуди флуидне варијације појавности. О томе пише Гастон Башлар у свом делу: „Вода и снови”. Поредећи огледало и мирну површину воде, он каже да вода служи томе да нашу слику учини природном, а код огледала налазимо на отпор стакла и метала који је препрека Нарцисовој намери огледања, као што је у досадашњим тумачењима (Башлар 1998: 32) већ примећено. На оба примера наилазимо у драми „Максим Црнојевић”. На почетку, Анђелија гледа у морску површину и ту јој се указује Максимов лик, онакав какав би требало да буде, природан и неспутан, флуидан, може се рећи и улепшан, зато што заједно са водом учествује у сили обожења природе и тиме и сам бива обожен, учесник једног непрекидног процеса стварања. Анђелија замишља: „на воденом огледалу му лик" (Костић 1962: 13). Са друге стране, у тренутку када опази

\footnotetext{
${ }^{3}$ На овакву формулацију наилазимо у: Несторовић, Зорица: Богови, ияареви, људи: трагички јунак у српској драми ХІХ века.
} 
своју ружноћу, Максим се огледа у правом огледалу и напада га, зато што он пружа изоштрену, бескомпромисну слику коју нико не може улепшати. Зато се, између осталог, Гастон Башлар у вези са овом позицијом Нарциса и пита: „Против чега се [Нарцис]огледа?” Овде се Максим огледа против себе, зато што огледало као његов прави одраз постаје супротност његове замишљене слике. Више се не огледа лепи већ ружни Нарцис и то боли целу природу, зато што она сама учествује у његовом огледању (Башлар 1998: 32). Са Максимом се у овом огледалу огледа и читав његов народ, он у огледалу има два супарника: огледало у коме се огледа и оно што се огледа поред њега самог. Ту се налази један од његових проблема, али не и основни. „Максим није Нарцис. Нарцис су други” (Несторовић 2007: 199). Ова одлична констатација заправо је кључна за разумевање начина огледања и гледања Максимовог лика. Желећи да се увери у своју лепоту, он наилази на ругобу, и због тога не бива сам суштински несрећан (не само због тога), несрећни постају други. Он за својом лепотом не жали, зато што му она није преко потребна, већ зато што је потребна другима. У тренутку кад се остали погледају у огледало заједно са Максимом схватају да и њих одређује телесна ругоба и зато не пева цела природа са Максимом, већ се чују клетве из главе целог колектива, зато што он, због новонастале ситуације, пропада. Важно је споменути још један тренутак огледања Максимовог лика. Наиме, на самом почетку драме из разговора Филете и Анђелије сазнајемо да Анђелија везе Максимов лик, уместо лика свог брата. То је огледање у стварању. На том месту треба призвати Платона који је везу лепоте и љубави видео управо у новом стварању и рођењу бића. Можемо ли овде тврдити да Анђелија везом, заправо на неки начин (ре)креира Максима? Да ли је њен вез само вез обузетости лепотом или је то вез у коме учествује и љубав заједно с њом? О томе ваља расправити на другом месту, након одређења лепоте по себи.

\section{Против кога се огледа Максим?}

Које су све компоненте Максимове лепоте? Потпуно је јасно да у његовом лику не можемо препознати све особине нарцисоидне појавности, зато што у самој драми ми не видимо њега како у њој ужива. Максим се у драми не огледа као леп, већ као ружан човек. Као леп, он се огледа само у очима других, а као ружан говори о лепоти душе. ${ }^{4}$ У „Гозби” Федар каже, да Ерот јесте стид „пред срамотом и надметање за лепотом” (Платон 2008:

\footnotetext{
${ }^{4}$ Антинарцистичка природа главног јунака у сукобу је са доживљајем његовог бића као нарцистичког који у њему имају сви остали јунаци ( в. Несторовић 2007: 198).
} 
20). Овде се Максим на неки начин стиди свог постојања само кроз појавност и надмеће се за лепоту душе, односно за љубав. Можемо ли се питати да ли се Максим стиди због своје нове појавности и надмеће за неку нову физичку лепоту? То би било мало вероватно, зато што он не тражи своје ново лице (истина, други га намећу у лику његовог побратима Милоша), већ тражи себе са већ постојећим лицем, односно тражи ону обједињујућу компоненту - љубав. Да ли је та друга компонента оквир новог огледања и да ли је тај оквир новог огледања смештен у праву особу - Анђелију? Овде се можемо поиграти са Башларом и питати се: „Против кога Максим воли?” Већ на самом почетку драме, Филета каже Анђелији:

У очима ти страсти гледају,

у страстима је угин'о ти вид (Костић 1962: 10)

У каквој се ту љубави може радити, када су у њој страсти основни покретачки мотив? Ова Филетина тврдња не мора се поштовати као тачна, уколико не бисмо знали даљи развој драмске радње. Анђелија неће волети ружног Максима, што значи да је за њу појавност, отуда и страст, основна компонента љубави. У том смислу, можемо се сетити и Паусанијиног говора у Платоновој „Гозби” која, разликујући природе Ерота, наводи да их има два. Један од њих је онај којим љубе нижи људи, односно они који: „љубе више тело него ли душу” (Платон 2008: 25). Стога се може закључити да Максим воли ону којој је његова лепота утемељујућа и основна. Ирина Деретић, наводи да опозиција коју Паусанија уводи, није само у вези са разликом између телесне и духовне љубави, већ постоји да: „би се показало да објект љубави као и модус њеног испољавања одређују како ће она бити окарактерисана" (Ђурић 1982: 543). Занимљиво је управо то да Анђелијин модус љубави, јесте био модус телесног и зато она не успева да сагледа оно што је у основи ње саме. У основи своје лепоте Максим тражи оно што представља њену суштину, а то је лепота његове душе. Лепо мора имати сећање на своје првобитно порекло, а оно није искључиво физичке природе. „Идеја је у појавној ствари час присутна, час није” (Ђурић 1982: 543). Овај Ђурићев став важан је како би се показало, да се идеја о Максимовој лепоти није изгубила у његовој тренутној ружноћи: она и даље постоји. Међутим, за њено схватање недостаје моменат сазнања.

Зашто се Максим не може волети? Одговор не тражимо само у његовој личности, већ и у личности онога ко би њега требало да воли, тј. у Анђелији. Описујући мит о Нарцису, Гастон Башлар примећује да је: „Ехо са Нарцисом. Она је он” (Башлар 1998: 34). Да ли би Ехо остала да живи 
у/са ружном Нарцису? Можда и би, зато што Нарциса није она учинила таквим, већ је он то постао сам од себе. Она је била спремна да апсолутно поништи себе, да буде биљка у води у којој се он огледа. У том смислу, била би спремна и да га воли ружног јер уме да воли. Федар, у својој беседи наводи управо то да је врхунска љубав она „љубав која се јавља када смо спремни да због оног којег волимо жртвујемо оно највише што имамо, а то је властити живот". ${ }^{5}$ Овде имамо неку врсту обрнуте позиције. Ехо воли Нарциса зато што уме да воли, а Анђелија воли Максима зато што је леп. То не искључује чињеницу да је Нарцис леп, али искључује могућност да би Анђелија волела Максима ако постане ружан. Овај, истина непотпуни силогизам, не рачуна на једну, у литератури (в. Несторовић 2007: 199) већ поменуту чињеницу, да Максим није Нарцис, али сам по себи има смисла када се говори о начину и врсти љубави коју осећају две јунакиње. Постоји још једна значајна сличност између Максима и Нарциса, а тиче се директно љубави.

Обојица воле оно што је недостижно, а то недостижно није само по себи такво, већ га они таквим чине. Нарцису је он сам себи недостижан као предмет обожавања, због тога што се он сам заљубио у своју слику, а Максиму је Анђелија недостижна зато што је он поружнео. Постоји, међутим, једна разлика: Нарцис сам себи никад неће постати достижан, али Анђелија би могла бити достижна Максиму. Међутим, она то не жели. У том смислу то није сасвим Максимов избор. Напоменимо још један елемент. Нарцисов Ерот је прави платоновски, он воли оно што је лепо и хармонично, код њега су Афродита и Ерот заиста рођени истог дана. Желећи себе да схвати кроз утемељујућу суштину љубави, Максим тражи исто - да воли лепоту лепе душе. Анђелија то није. Значи ли то да би Максим могао волети самога себе? Да, уколико би се десило да Максим као ружан Нарцис, буде и даље Нарцис у сваком смислу те речи.

\section{Светао дан као белило и тамна ноћ као ружноћа}

Категорије белине и светлости, одређујуће су за разумевање лика Максима Црнојевића. Није чудно да се као основна карактеристика лика, издвајају његове очи. Отац ће то истаћи, приликом разговора са Млетачким дуждом:

\footnotetext{
${ }^{5}$ Овакви интерпретацију Федровог исказа доноси Ирина Деретић (в. Деретић 2014: 104).
} 
Видиш ли тамо онај висок стуб,

У том је стубу од камена лав,

У њега очи до два алема

$[\ldots]$

Још сјајније су очи Максима (Костић 1962: 18).

Очи саме у себи садрже потенцију светлости и зато оне јесу, како то Лаза Костић пише у свом есеју, „најмањи простор кроз кога се виде несагледиве даљине.” Он посебно испитује природу и састав ока, притом истичући карактеристике сваког дела појединачно. Нас овде занимају представе очију, као она места за које се везује значење светлости. Овај мотив је учестао у књижевности. Поменимо онај део у „Лучи микрокозма” у којем се говори да је потребно променити очи да би душа била способна да угледа Творца. У „Максиму Црнојевићу”, изостаје та врста трансцеденције. Овде очи имају потенцију и огледања, и гледања. Помоћу њих доказује се то да је Максим леп, најлепши од свих, али се истовремено помоћу њих и спознаје да је ружан. Максимов лик се пореди још са светлим сунцем, а сватови који би дошли за Анђелију са светлим звездама:

И док се месец снова испуни,

Нек се испуне и моји дворови,

Сватова наших светлим звездама,

И зетом мојим сјајним месецом (Костић 1962: 22).

Опис овакве лепоте, која се доводи у везу са светлошћу и одблеском светлости у човеку, типично је хеленски. Код старих Грка, светлост је увек довођена у везу са лепотом и изузетношћу, а то да је одблесак или искра једне свеопште светлости, мисао је Плотина који је говорио о Једном, као оном наткосмичком светлошћу које садржи све остале светлости. Слична идеја тематизована је и у већ поменутом Његошевом спеву. Али, какве везе има светлост (назначена као главна ознака лепоте) са љубављу и шта је у томе хеленско? Светлост као таква у себи садржи савршену хармонију и склад и што је још врло важно - апсолутну чистоту. Као главна ознака Максимове лепоте, она постаје узус схватање апсолутне лепоте, у том смислу и апсолутне љубав. Може се волети само оно што је чисто, неиспрљано. Насупрот томе, он себе пореди са „црним врагом”, своју природу пореди са изношеном црном хаљином, из себе чује „промукли врашки глас". Све ове особине, које он на себи уочава, јесу оне особине, које упућују на то да се за њега не везује оно што је чисто, већ оно што је прљаво, а љубав не сме доћи у везу са нечим таквим. У Платоновој „Гозби” Ериксимах каже: „Другачија је љубав у оном што је здраво, а 
другачија опет у оном што је болесно" (Платон 2008: 35). На тај начин Ериксимах жели да споји телесно и духовно у осећају апсолутне љубави (Деретић 2014: 107). Али, Максим престаје да буде леп и тиме се губи ова компонента телесности, као једног од конститутивних чинилаца савршено лепог. Да ли се на тај начин може оправдати то што Анђелија не може да воли ружног Максима? У његовом телу више не пребива анђео и оно не сија светлошћу, прекривено је крастама и црни се, а такво се тело не може волети. Да ли се у овом случају може волети свет око Максима? На самом почетку указали смо на везу целог окружења са Максимом, као и на то да оно од њега директно зависи. Ако се природа цела огледала у лепом Максиму, она то сада ради и са ружним Максимом. И зато његов отац, поставши свестан какав је сада његов син, изговара:

Ох, свете мој, да светао беше ти,

Док на твом лицу сјаше бели дан,

Ал више дана ја те не видох,

Па и на теби данак престаде,

И окрену се друга страна - ноћ (Костић 1962: 40).

Свет постаје таман зато што Максим више није леп. Као такав он се не може волети. То га води да тражи потврду љубави у нечем другом.

\section{Зашто Максим није ружан?}

Може ли се волети Максим и зашто Максим није ружан? Он у једном делу драме каже: „Срце је моје, пуно, препуно, испуњава га само један лик" (Костић 1962: 34). Тај лик је Анђелијин. Са једне стране, љубав је била послата, али да ли се умело на њу одговорити. Чини се - не сасвим. Анђелија је волела Максима и то се види још на почетку драме али се исто тако чини да је она била на најнижем платоновском ступњу љубави. Њена љубав се није ширила и множила, већ је остајала иста, осуђена на појавно и физичко, отуда она није била способна да дође до оног ступња љубави који би се могао означити као апсолутно давање и узимање. Смисао сопствене егзистенције, Максим налази у „постојању кроз љубав” (Несторовић 2007: 191). Али у његовој егзистенцији учествују и други, тј. она се мора и од стране других схватити на исти тај начин. Међутим, то се не дешава, Максим остаје онај који је био леп и онај који не постоји, ако је такав. Са друге стране, он тежи да се роди у љубави. То рађање, било би потпуна промена лика, оног на кога су сви до сада навикли, зато што љубав јесте ново стварање и нова креација. У том смислу, Максим се пита како је могуће да Анђелија љуби Милоша, а не њега. Он је рачунао 
на то да Анђелија јесте на оном највишем платоновском ступњу љубави и да пољубац као савршени сусрет, може значити и апсолутну спознају. Она је на другој страни волела лепо и чисто лице, не лепу и чисту душу. Са тим Максим није успео да се помири.

Диотима пита Сократа: „Или мислиш ли да оно што није лепо, мора баш бити ружно?" (Платон 2008: 64). Она Ерота наилази на средини, између смртна и бесмртна. Између људи и богова.

А бог се не меша са човеком, него преко овога врши се сав саобраћај и разговор богова са људима, и на јави и у сну (Платон 2008: 63).

У том смислу Аница Савић- Ребац истиче („Платонска и хришћанска љубав) да Ерот јесте та једина веза између душе и апсолутног, односно бога и људи, као и да је он сам пут ка мистичком обожењу. Та љубав као посредник, мора бити на највишем ступњу свог развоја, мора постати онај Ерос, како каже ова ауторка, који се спојио са агапе и у њој ишчезао. Такву љубав не осећају ни Максим ни Анђелија. Отуда за њих не можемо рећи да се налазе негде између, у функцији Ерота, зато што они на свом ступњу љубави никако не расту. Они задржавају своје позиције, у радикално измењеном поретку, важном по њихове животе. У том смислу уздизање (ascensus), мора бити основна компонента понашања, зато што уздизати се, значи - волети. Путовати од људске душе ка божанској, значи усавршавати себе у врлини љубави. У том смислу је за старе Грке било важно сазнање, као врхунско начело. Сазнање божије је апсолутно сазнање човека усавршеног у врлини љубави. Код Платона се разликује оно што је мишљење од оног што је знање. Знање се бави, у овом случају, лепотом као таквом (Расел 1962: 136). Лепота би требало да претендује на смисао апсолутности, а тај смисао се налази у основи њене концепције тј. у лепоти душе. Анђелија није поседовала знање о лепоти, она је њу само опажала и због тога није успела да дође до њене суштине. Најприближније знању о лепоти, нашао се Лаза Костић, спевавши једну од највећих песама српске поезије, „Santa Maria della Salute”. Песник узвикује: „У рај, у рај, у њезин загрљај!” Њено станиште је постављено на пиједесталу божанства, и уздизање ка њој јесте Платонов Ерот, као пут ка обожењу, мада у овој песми постоји и онај други пут, пут агапе, оне љубави која се својом милошћу спушта на земљу. Та два смера се укрштају у овој песми. Она као божанство силази на земљу, а он се као обичан смртник уздиже ка њој.

Ова нешто већа дигресија у вези са познатом песмом Лазе Костића, имала је циљ управо да покаже немогућност остварења ероса, самим тим и агапе у драми „Максим Црнојевић”. Постоји још неколико занимљивих 
места у Диотиминој беседи, на које би требало, сасвим извесно, указати. Диотима каже: „Љубав тежи на то да јој увек припада оно што је добро. (...) То је управо рађање у лепоти и телом и душом" (Платон 2008: 72). Два момента из овог исказа су важна за разумевање драме „Максим Црнојевић”. Пре свега, Максим тежи да своје постојање утемељи у љубави и да она постане одређујућа за његово биће. Дакле, он тежи да му припада оно што је апсолутно садржано добро, а то је најпре љубав. Са друге стране, то апсолутно добро тражи и од Анђелије. Њено усавршавање у добру, био би заједнички пут ка обожењу и уздизању. Са друге стране, он жели да се поново роди у љубави, у платоновском смислу то би било, поновно рађање и у лепоти, али оној која би подразумевала и душу, и тело. У вези са мотивом рађања у љубави, треба се још једном обратити Федровој беседи у којој он Ерота сматра најстаријим од свих богова, и то се разумева као његова способност да буде „у основи свих рађања” (Платон 2008: 72). Постојање у љубави је самим тим постојање у једном свеобнављајућем поретку наших бића и у вечном враћању младости самој љубави. ${ }^{6}$ Федар као да је Ерот најстарији, а Агатон да је намлађи од свих богова. Он је можда и једно и друго - примарна сила чија могућност обнављања никад неће бити испражњена.

Пред крај, Диотима и Сократ разговарају: „Јер љубави, Сократе, није до лепоте, као што ти мислиш”. Сократ је пита: „Него до чега”? Диотима на то одговара: „До зачињања и до рађања у лепоти” (Платон 2008: 73). Управо је то важно за Максима. Њему није стало до лепоте као такве, већ до рађања у њој, до поновног успостављања љубави као врхунског начела које се састоји у љубави. Одговор на горе постављено питање у вези са тим да ли се може волети Максим и зашто он није ружан, има неколико могућих варијација. Пре свега, Максим се може волети у тренутку када је постао ружан на исти начин као и када је био леп, уколико се у том тренутку могло говорити о љубави. Са друге стране, он није ружан, зато што тежи ономе што је основно начело платонизма: хармонији и симетрији душе у спознању врхунског начела љубави. Он има жељу за усавршавањем у добру. У том смислу, Максим није и не може бити ружан. Не воли се оно што је дисхармонично. Са друге стране, он се труди да у себи постигне склад, до кога истина неће доћи, али

\footnotetext{
${ }^{6}$ Ирина Деретић, у својој студији, разлику између Федрове и Агатонове беседе налази у њиховим гледиштима на старост односно младост Еротову. Старост би представљала управо примарност и неку врсту првобитног учешћа у процесу стварања космичког поретка, а младост - потенцију сталног обнављања.
} 
је на тренутак покушао ићи степеницама обожења. Након Максимове песме, Анђелија признаје:

Голубица је свему крива том

Испод перја што није познала

Незагашен остатак милости

Неприличну љубав (Костић 1962: 120).

Кроз целу драму она слути нешто што ће се десити и ставља себи неку врсту аутосугестије али не успева до краја да је освести. Њој недостаје, већ поменута компонента сазнања. Свесна је да се испод перја мора налазити велика љубав, али не успева да је сагледа и упозна до краја. Имплицитно, на неки начин признаје своју кривицу, која је опет на неки начин била кривица из незнања али оног које у себе није укључивало љубав као основни регулаторни принцип. На крају ни Максим не успева да дође до последњег платоновског ступња љубави, зато што не успева да нађе друго утемељење свог бића сем оног пронађеног у лепоти. Лепота је остала коб, али се та коб прелила и на идеју љубави. Љубав и лепота су само у мистичном сагласју остале једно.

Према Платоновој концепцији, љубав мора бити рођена у савршеној лепоти, али та лепота не може бити физичка, већ лепота душе. Ако душа постане зла и недостојна бића, пут је за њу затворен, зато што Ерот јесте уздизање и обожење, а обожити се могу само они достојни божанства. Драма „Максим Црнојевић” Лазе Костића поставила је питање о важност и статусу лепоте у свету. У њој је направљена разлика између физичке и духовне лепоте и проговорено о основним начелима ње саме. О лепоти се говорило у смислу физичке појавности и у ту расправу је било и више него потребно увести лик Нарциса, не због нарцисоидног комплекса, већ због тога што је и Нарцису била онемогућена љубав, односно није био способан да има оно што највише воли. Такав је био и Максим. Због себе самог, односно због своје физичке промене, он није могао да воли оно до чега му је највише стало у животу. Смисао је тражио управо у љубави, али не било каквој, већ оној љубави која подразумева добро. У том смислу, на њега се може применити Платонов став о обавези човека да воли само оно што је добро јер је то једино могуће поље тражења бесмртности. Мора се волети оно што је достојно љубави, не било шта и било ко. Љубав, према Платону је неко стање између, тј. стање које представља пут од човека 
према Богу, од душе према трансцеденцији. Отуда је Максим покушавао да се ослободи оног телесног да би дошао до оног апсолутног и општег. Ружан Максим се може волети, зато што се усавршавао у добру, тј. у жељи да врхунско начело његовог живота постане чиста љубав.

\section{Литература}

Башлар 1998: Г. Башлар, Вода и снови, Сремски Карловци, Нови Сад: Издавачка књижарница Зорана Стојановића.

Деретић 2014: И. Деретић, Платонова филозофска митологија: студија о Платоновим митовима, Београд: Завод за уџбенике.

Ђурић 1982: М. Ђурић, Историја хеленске книжевности, Београд: Завод за уџбенике и наставна средства.

Костић 1962: Л. Костић, Максим Црнојевић, Одабрана дела II, Нови Сад, Београд: Матица српска-СКЗ.

Костић 1965: Л. Костић, Лаза: Огледи, Београд: Нолит.

Несторовић 2007: 3. Несторовић, Богови, цареви, људи: трагички јунак у српској драми XIX века, Београд: Чигоја штампа.

Платон 2008: Платон, Гозба, Београд: Дерета.

Расел 1962: Б. Расел, Историја западне филозофије, Београд: Космос.

Савић-Ребац 1966: А. Савић-Ребац, Хеленски видиии, Београд: СКЗ.

Jovana D. Milovancevic

\section{PLATO'S CONCEPT OF BEAUTY AND LOVE IN LAZA KOSTIC'S PLAY „MAKSIM CRNOJEVIC”}

\section{Summary}

On the asked question about beauty as the foothold of each person, character of Maksim Crnojevic responds with the love as an essence. Collective sees him as a Narcis, which in drama he actually is not. He wants to love a beautiful soul, but in a dialogue with it, he does not succeed in finding a true correspondent. His character is seen as a light of a physical being, but he searches for the elementary light, marked as knowledge. Making a difference between kinds of love, in his dialogues, Plato suggests the need to worship something true and elementary. Because of it, at the end, Maksim doesn't stay ugly, because he is capable of loving with genuine love and because of that he is on a Plato's way of deification.

Key words: Plato, Maksim Crnojevic, love, beauty, Narcis, soul. 